\title{
REVIEW
}

\section{Exposure to environmental tobacco smoke and adult non-neoplastic respiratory diseases}

\author{
J. Trédaniel**, P. Boffetta*, R. Saracci*, A. Hirsch
}

\begin{abstract}
Exposure to environmental tobacco smoke and adult non-neoplastic respiratory diseases. J. Trédaniel, P. Boffetta, R. Saracci, A. Hirsch. CERS Journals Ltd 1994.

ABSTRACT: Exposure to environmental tobacco smoke (ETS) is widespread in European countries, the most serious exposures occurring at home and in the workplace. Epidemiological studies have, essentially, addressed the association between ETS exposure and respiratory health in children, and increased risk of lung cancer among adult nonsmokers. Relatively few studies have been reported on ETS and adult non-neoplastic respiratory diseases.

On the basis of the available data, no definite conclusion (excluding the acute irritating effect of ETS on respiratory mucous membranes) can be drawn. Although biologically plausible, it remains controversial whether ETS exposure is associated with chronic respiratory symptoms and occurrence of chronic obstructive pulmonary disease, including asthma. Most of the studies that have used the most sensitive indicators of pulmonary function have suggested a negative impact of ETS exposure. However, if really present, the physiological significance of such small changes is unclear, and the relationship to long-term changes in lung function is not established. Moreover, the possibility of bias and confounding factors must be taken into account. Thus, there is a need for further epidemiological studies on ETS exposure and adult non-neoplastic respiratory disorders. Eur Respir J., 1994, 7, 173-185.
\end{abstract}

\author{
*Unit of Analytical Epidemiology, Intern- \\ ational Agency for Research on Cancer, \\ Lyon, France. ${ }^{\dagger}$ Service de Pneumologie, \\ Hôpital Saint-Louis, Paris, France. \\ Correspondence: J. Trédaniel \\ International Agency for Research on Cancer \\ 150 Cours Albert Thomas \\ 69372 Lyon cedex 08 \\ France \\ Keywords: Asthma \\ chronic obstructive pulmonary disease \\ environmental tobacco smoke \\ pulmonary function \\ pulmonary symptoms \\ Received: March 151993 \\ Accepted after revision July 271993 \\ This study was partially supported by the \\ European Concerted Action on Passive \\ Smoking (EUROPASS) of the Commission \\ of the European Communities.
}

Cigarette smoking has been identified as the single most important source of preventable morbidity and premature mortality [1-5].

Passive smoking, involuntary smoking, and exposure to environmental tobacco smoke (ETS), are used synonymously to describe the involuntary exposure of nonsmokers, both children and adults, to tobacco combustion products generated by smokers. ETS comprises the amount of tobacco smoke which is not inhaled by the smoker (sidestream smoke-SS), as well as the portion of inhaled smoke (mainstream smoke) which is not retained in the smoker's lung, and is exhaled into the environment. In enclosed spaces, smoke accumulates, and the concentration varies with the number of smokers, with the type of smoking, and with the characteristics of the room, especially the ventilation. Although the exposures to active smoke and ETS are not identical, the latter appears to include most tobacco combustion byproducts, including irritants, and carcinogens [2, 6-8].

The level of exposure to ETS, based on biochemical markers, such as salivary and urinary concentrations of nicotine and cotinine, has been estimated to be equivalent to $0.1-2$ cigarettes $\cdot$ day $^{-1}$ [9-14]. The ubiquitousness of tobacco smoke in homes, workplaces, public areas (with especially high concentrations measured in bars or taverns [15]), and private establishments, makes exposure to ETS virtually unavoidable. For instance, in a population study of 37,881 nonsmokers and former smokers, $63 \%$ of the nonsmokers reported some daily exposure; $35 \%$ were exposed at least $10 \mathrm{~h} \cdot \mathrm{week}^{-1}$, and $16 \%$ at least $40 \mathrm{~h} \cdot$ week $^{-1}$ [16]. During the study of health and the environment and evaluation of particulate matter in Tucson, Arizona, LeBowitz et al. [17] found that $39 \%$ of the population were exposed to ETS. To investigate to what extent questionnaires can indicate exposure levels to ETS, the International Agency for Research on Cancer (IARC) conducted a multicentre study, which included 1,369 nonsmoking women. Of the total, 20\% of the subjects had nondetectable urinary cotinine levels, indicating that they were true unexposed nonsmokers. Analyses of self-report for these subjects revealed that $60 \%$ of them were not exposed outside the home, and $89 \%$ reported that they had no exposure from a husband who smoked [18].

During the last $15 \mathrm{yrs}$, attention has been focused on the potential health effects of ETS [19-22]. When this topic was first raised in the 1972 Report of the Surgeon General [23], only a handful of studies had addressed this issue, and provided limited information. The 1984 Report on Chronic Obstructive Lung Disease [24] devoted more attention to ETS. Recent assessments have definitely concluded that the involuntary inhalation of cigarette smoke by nonsmokers causes disease, most notably lung cancer $(2,25-28)$. 
There is also cumulative evidence that parental smoking, especially of the mother, is associated with increased prevalence of respiratory symptoms, increased incidence of acute respiratory infections, and decreased lung function, with a small reduction in their rate of pulmonary growth and development in children of smoking parents $[28,29]$. The combination of epidemiological studies with the demonstration of physiological changes with exposure to ETS, together with biochemical evidence that elements of ETS have adverse effects on the cardiovascular system, has been interpreted as supportive of the hypothesis that ETS may cause coronary heart disease [30, 31].

Conversely, the effects of ETS on the risk of nonneoplastic respiratory diseases in adults have not been fully clarified. Several reviews of the literature on ETS have addressed some aspects of this problem [19, 20, 22, $29,32,33]$, but a recent comprehensive review is lacking, particularly as ETS exposure in the workplace assumes increasing importance as an occupational health issue $[34,35]$. The aim of this article is to review currently available data concerning ETS and lung function, respiratory symptoms, and respiratory diseases (excluding lung cancer) in nonsmoking adults.

\section{Acute effects}

The determination of acute effects of ETS is difficult, because the observed reactions, although immediate, are largely subjective [36]. Nonsmokers seem to react significantly more than do smokers [37].

The most common effect is tissue irritation, especially of the eyes, but also of the nose, throat and airways [37-39]. WeBER et al. [40] exposed 60 subjects to ETS in a climatic chamber: approximately one third of normal nonsmokers experienced eye irritation, headache, and rhinitis; the effects on throat and respiratory system were relatively small [40]. Acrolein was the most notable irritant measured. LEBOwITZ et al. [17] found an increased prevalence of acute respiratory symptoms as indoor ETS increases, especially in households from the lower socio-economic status. Complaints are especially marked amongst aircraft passengers [41-43].

PIMm et al. [44] exposed 20 nonsmoking adults to ETS for $2 \mathrm{~h}$ on alternate days. Maximal expiratory flow at $25 \%$ forced vital capacity $\left(\mathrm{MEF}_{25}\right)$ decreased slightly with smoke exposure. No other consistent changes in lung function were observed. Despite the small amount of physiological change, most subjects found the exposure to cigarette smoke unpleasant. Similar results were found by SHEPHARD et al. [45], who exposed 23 young healthy adults to $2 \mathrm{~h}$ of ETS and observed a small (3-4\%) decrease of dynamic lung volumes. BASCOM et al. [46] exposed 10 historically ETS-sensitive and 11 historically ETSnonsensitive subjects to $15 \mathrm{~min}$ of clean air, followed by 15 min of a high concentration of ETS. Pulmonary function changes were of a small magnitude $(<7 \%)$ in both groups. However, sensitive subjects showed significant decrements in forced volume capacity (FVC), forced expiratory volume in one second $\left(\mathrm{FEV}_{1}\right)$, and mean expiratory flow during the middle half of the FVC $\left(\mathrm{FEF}_{25-75}\right)$ after smoke. The $\mathrm{FEF}_{25-75}$ continued to remain significantly decreased $20 \mathrm{~min}$ after cessation of exposure.

\section{Chronic respiratory symptoms}

There are no studies of chronic ear, nose and throat symptoms in adults exposed to ETS. Nearly $25 \%$ of 10,000 nonsmoking office-workers reported exacerbation of pre-existing pulmonary conditions, when working with a smoker [47].

Few studies have addressed the effect of ETS exposure on chronic respiratory symptoms (persistent cough, phlegm, wheezing) in nonsmoking adults with ETS exposure. They are summarized in table 1 .

LEBOWITZ and BuRROws [48] studied chronic respiratory symptoms in a community population of 3,484 individuals from Tucson, Arizona; 1,258 adults were lifelong nonsmokers. There was no significant trend in their symptoms in relation to the smoking status of other family members.

As part of a large survey in three USA towns, SchILLING et al. [56] studied respiratory symptoms, diseases and lung function in 376 white families. Symptom prevalence in nonsmokers was unrelated to whether or not their spouses smoked. The records of 1,724 residents of Washington County, Maryland were analysed to evaluate the effects of ETS exposure [49]. The frequency of major respiratory symptoms (cough, phlegm, wheeze, breathlessness, chest illness) showed no evidence of an association with the presence of a cigarette smoker in the household.

KAUFFMANN et al. [50, 51] conducted a parallel analysis on two large female populations, enrolled, respectively, in the US Six Cities study (2,200 women) [57] and the French PAARC study (3,855 women) [58]. One thousand nine hundred and twenty seven women (32\%) were exposed to ETS from their current spouse. Over all, a weak association was found between ETS exposure and respiratory symptoms, which was of borderline signification for wheeze and dyspnoea. No association was observed with cough or phlegm production.

A prospective cohort study was carried out in an urban West Scotland population, the members of which were homogeneous for social class and ethnic group [52, 59]. From the original cohort, 243 men and 1,295 women were ETS exposed. For each of the four respiratory symptoms studied (infected sputum, persistent sputum, dyspnoea and hypersecretion) the rates in the ETS exposed group were nonsignificantly higher than those in the control group (unexposed nonsmokers).

SCHWARTZ and Zeger [53, 54] re-examined the data originally obtained from a cohort of 100 student nurses in Los Angeles [60, 61] recruited for a diary study of acute effects of air pollution. Diaries were completed weekly, for as long as 3 yrs. Controlling for active smoking, a smoking room-mate increased the risk of an episode of phlegm (relative risk $(R R)=1.41$ ) but not of cough. 
Table 1. - Studies of environmental tobacco smoke (ETS) and chronic respiratory symptoms

\begin{tabular}{|c|c|c|c|c|c|c|c|c|}
\hline \multirow{2}{*}{$\begin{array}{l}\text { First author } \\
\text { Year, Country } \\
\text { [Ref.] }\end{array}$} & \multirow{2}{*}{$\begin{array}{c}\text { ETS } \\
\text { exposed } \\
\text { subjects }\end{array}$} & \multirow{2}{*}{$\begin{array}{l}\text { Measure } \\
\text { of risk }\end{array}$} & \multirow[t]{2}{*}{ Categories } & \multicolumn{5}{|c|}{ Results } \\
\hline & & & & Cough & Phlegm & Wheeze & Dyspnoea & Colds \\
\hline LEBOWITZ & 1258 & Preva- & Smoker & 6.8 & 8.6 & 4.5 & & \\
\hline 1976, USA & & lence & Ex-smoker & 8.1 & 6.5 & 5.5 & & \\
\hline [4] & & rate $\%$ & Nonsmoker & 10.3 & 8.6 & 4.4 & & \\
\hline Сомsтоск & 539 & $\mathrm{RR}$ & Male & 0.96 & 0.90 & 1.04 & & \\
\hline $\begin{array}{l}\text { 1981, USA } \\
\text { [49] }\end{array}$ & $\begin{array}{r}(426 \mathrm{M}, \\
113 \mathrm{~F})\end{array}$ & & Female & 0.17 & 0.72 & 1.45 & & \\
\hline KAUFFMAN & 1476 & RR & France & 1.35 & 0.77 & 1.03 & 1.17 & \\
\hline 1989, USA/ & French & & & $(0.8-2.4)$ & $(0.3-2.0)$ & $(0.8-1.4)$ & $(0.8-1.6)$ & \\
\hline $\begin{array}{l}\text { France } \\
{[50,51]}\end{array}$ & +451 USA & & USA & $\begin{array}{c}1.4 \\
(0.6-2.1)\end{array}$ & $\begin{array}{c}1.65 \\
(0.7-3.8)\end{array}$ & $\begin{array}{c}1.35 \\
(1.0-1.9)\end{array}$ & $\begin{array}{c}1.35 \\
(0.7-2.6)\end{array}$ & \\
\hline $\begin{array}{l}\text { HoLE } \\
\text { 1989, Scotland } \\
\text { [52] }\end{array}$ & $\begin{array}{l}1538 \\
(243 \mathrm{M}, \\
1295 \mathrm{~F})\end{array}$ & RR & & & $\begin{array}{c}1.21 \\
(0.8-1.8)\end{array}$ & & $\begin{array}{c}1.09 \\
(0.8-1.4)\end{array}$ & \\
\hline $\begin{array}{l}\text { SCHWARTZ } \\
1990, \text { USA } \\
{[53,54]}\end{array}$ & 100 & RR & & & $\begin{array}{c}1.41 \\
(1.1-1.9)\end{array}$ & & & \\
\hline $\begin{array}{l}\text { White } \\
\text { 1991, USA } \\
\text { [55] }\end{array}$ & 80 & $\begin{array}{l}\text { Preva- } \\
\text { lence } \\
\text { rate } \%\end{array}$ & $\begin{array}{l}\text { Exposed } \\
\text { Unexposed }\end{array}$ & $\begin{array}{l}70 \\
25\end{array}$ & $\begin{array}{l}67.5 \\
20\end{array}$ & & $\begin{array}{l}67.5 \\
15\end{array}$ & $\begin{array}{l}85 \\
20\end{array}$ \\
\hline
\end{tabular}

RR: relative risk.

White et al. [55] reported a study investigating the effects of workplace ETS exposure on the prevalence and symptoms of respiratory illness among 40 ETS exposed and 40 unexposed nonsmokers. Passive smokers experienced more respiratory symptoms than nonsmokers, namely chronic cough (70 versus $25 \%$ ), chronic phlegm (68 versus $20 \%$ ), shortness of breath (68 versus $15 \%$ ), and chest illnesses (85 versus $20 \%$ ). Passive smokers missed twice as many workdays due to chest illness during an average 12 month period than did nonsmokers $(\mathrm{p}<0.05)$.

\section{Lung function testing}

It is important to appreciate whether or not healthy adults exposed to ETS may have changes in pulmonary function that may eventually lead them to the development of a chronic obstructive pulmonary disease (COPD). A number of studies have been published on the effects of ETS and pulmonary function in adults. However, these investigations were often initiated within the framework of research projects not primarily concerned with ETS. As a result, certain reservations must be made regarding the relevance of some of the findings, due to the low sensitivity and low power of these studies. In particular, the older studies used spirometric tests of low sensitivity, such as $\mathrm{FEV}_{1}$ and FVC, which depend mainly on the total airway resistance and elastic recoil of the lung, and are not disturbed even in the presence of early small airways dysfunction, possibly representing the initial reaction of the bronchopulmonary system to the active inhalation of tobacco smoke. However, many recent studies have assessed the potential effects of ETS on small airways function by means of sensible parameters, such as mean forced expiratory flow during the middle half of the forced vital capacity $\left(\mathrm{FEF}_{25-75}\right)$ and the end of the FVC ( $\left.\mathrm{FEF}_{75-85}\right)$.

A number of studies (table 2) have failed to detect an association between ETS exposure and lung function. Schilling et al. [56] analysed the $\mathrm{FEV}_{1}$ in 330 families. In the families in which only one subject smoked (114 pairs), the nonsmoker's lung function was similar to that in which neither spouse smoked. The results for residual FVC and flow rates showed similar trends.

Comstock et al. [49] analysed the possible effects of household tobacco smoke on $\mathrm{FEV}_{1}$ and the ratio between $\mathrm{FEV}_{1}$ and forced vital capacity $\left(\mathrm{FEV}_{1} / \mathrm{FVC}\right)$ among 1,724 residents of Washington County, Maryland. In the subgroup of 93 nonsmokers who lived with a smoker, the lung function tests were similar to those observed in 325 unexposed nonsmokers.

As part of a case-control study of 20-39 year old nonsmoking female participants in the Tecumseh Community Health Study, JONES et al. [62] showed no significant effect on $\mathrm{FEV}_{1}$ from exposure to smokers in the home. 
Table 2. - Studies of environmental tobacco smoke (ETS) and lung function negative results

\begin{tabular}{|c|c|c|c|}
\hline $\begin{array}{l}\text { First author } \\
\text { Year, Country } \\
\text { [Ref.] }\end{array}$ & Subjects & $\begin{array}{l}\text { Pulmonary } \\
\text { function } \\
\text { measures }\end{array}$ & Results \\
\hline $\begin{array}{l}\text { SCHILLING } \\
\text { 1977, USA } \\
{[56]}\end{array}$ & $\begin{array}{l}330 \text { families } \\
\text { (114 with one } \\
\text { smoker) }\end{array}$ & $\mathrm{FVC}, \mathrm{FEV}_{1}$ & $\begin{array}{l}\text { No effect of the spouse's } \\
\text { smoking status on the } \\
\text { pulmonary function }\end{array}$ \\
\hline $\begin{array}{l}\text { Сом⿰тоск } \\
1981, \text { USA } \\
{[49]}\end{array}$ & $\begin{array}{l}418 \text { nonsmokers: } \\
93 \text { living } \\
\text { with a smoker }\end{array}$ & $\begin{array}{l}\mathrm{FVC}, \mathrm{FEV}_{1} \\
\mathrm{FEV}_{1} / \mathrm{FVC}\end{array}$ & $\begin{array}{l}\text { RR associated with a smoker } \\
\text { in the household: } \\
\mathrm{FEV}_{1}<80 \%: 1.42 \\
\text { FEV }_{1} / \mathrm{FVC}<70 \%: 1.19\end{array}$ \\
\hline $\begin{array}{l}\text { JONES } \\
1983 \text {, USA } \\
{[62]}\end{array}$ & $\begin{array}{l}213 \text { women, } \\
\text { aged } 20-39 \text { yrs }\end{array}$ & $\mathrm{FEV}_{1}$ & $\begin{array}{c}\% \text { of women living with a } \\
\text { smoker at home: } \\
\text { low } \mathrm{FEV}_{1}: 32.2 \% \\
\text { high } \mathrm{FEV}_{1}: 39.8 \%\end{array}$ \\
\hline $\begin{array}{l}\text { LEBOwITZ } \\
\text { 1984, USA } \\
{[63]}\end{array}$ & 271 families & $\begin{array}{l}\mathrm{FVC}, \mathrm{FEV}_{1} \\
\mathrm{MEF}_{50} \\
\mathrm{MEF}_{75}\end{array}$ & $\begin{array}{l}\text { No effect of the spouse's } \\
\text { smoking status on the } \\
\text { pulmonary function }\end{array}$ \\
\hline $\begin{array}{l}\text { LEBOwITZ } \\
1984, \text { USA } \\
{[64,65]}\end{array}$ & 117 families & PEF & $\begin{array}{l}\text { No effect of ETS exposure } \\
\text { on PEF, even in asthmatic } \\
\text { subjects }\end{array}$ \\
\hline $\begin{array}{l}\text { KENTNER } \\
\text { 1984, Germany } \\
{[66]}\end{array}$ & $\begin{array}{l}1351 \text { white collar: } 383 \\
\text { ETS exposed }\end{array}$ & $\begin{array}{l}\text { FVC } \\
\mathrm{FEF}_{25-75} \\
\mathrm{FEF}_{75-85}\end{array}$ & $\begin{array}{l}\text { No effect of ETS exposure } \\
\text { on the pulmonary function }\end{array}$ \\
\hline $\begin{array}{l}\text { LAURENT } \\
\text { 1992, France } \\
\text { [67] }\end{array}$ & $\begin{array}{l}14 \text { male } \\
\text { prisoners }\end{array}$ & $\begin{array}{l}\mathrm{FVC}, \mathrm{FEV}_{1} \\
\mathrm{MEF}_{25} \\
\mathrm{MEF}_{75}\end{array}$ & $\begin{array}{c}\text { No effect of daily ETS } \\
\text { exposure of } 13 \mathrm{~h} \text { during } \\
\text { a month }\end{array}$ \\
\hline
\end{tabular}

FVC: forced vital capacity; $\mathrm{FEV}_{1}$ : forced expiratory volume in one second; $\mathrm{MEF}_{50}$ and $\mathrm{MEF}_{75}$ : maximal expiratory flow at 50 and $75 \%$ of $\mathrm{FVC}$, respectively; $\mathrm{FEF}_{25-75}$ and $\mathrm{FEF}_{75-85}$ : forced expiratory flow during the middle half of FVC and at end FVC, respectively; PEF: peak expiratory flow; RR: relative risk.

LEBOwITZ et al. [63] analysed the family aggregation of pulmonary function measurements in the nuclear families of the Tucson Epidemiological Study of Airways Obstructive Diseases. There were 271 parental pairs and their children who had satisfactory pulmonary function data. No relationship was found between fathers' or mothers' smoking and their spouses' pulmonary function, judged on $\mathrm{FVC}, \mathrm{FEV}_{1}$, maximum expiratory flow at $50 \%$ $\left(\mathrm{MEF}_{50}\right)$ and $75 \%\left(\mathrm{MEF}_{75}\right)$ of FVC. In another analysis, 117 families (229 adults and children) were randomly selected and were studied over a 2 yr period, using daily symptom diaries and peak expiratory flow (PEF) meters $[64,65]$. There were no effects of ETS exposure on PEF (or symptoms) in adults.

KENTNER et al. [66] carried out an investigation involving 1,351 white collar workers, in Northern Bavaria. Information about active smoking and ETS exposure including exposure at home and in the workplace - was obtained by a standardized questionnaire. $\mathrm{FVC}, \mathrm{FEF}_{25-75}$, and $\mathrm{FEF}_{75-85}$, and maximal mid-expiratory flow (MMEF) were determined. In this study, passive smokers showed no decrease in their ventilatory parameters.
On their arrival in prison, 14 volunteer male, nonsmoking prisoners were put into a cell that was already occupied by three smokers [67]. Mean daily duration of ETS exposure was $13 \mathrm{~h}$. No significant difference could be demonstrated on $\mathrm{FEV}_{1}, \mathrm{FVC}, \mathrm{MEF}_{75}$, and $\mathrm{MEF}_{25}$ between the first and the 30th day of their imprisonment.

In contrast to these negative studies, a number of investigations have detected an association between ETS exposure and pulmonary function. They are summarized in table 3. Three early studies [68-70] had found no difference between ETS exposed and unexposed nonsmokers, either in FVC or in $\mathrm{FEV}_{1}$, but significantly lower values for $\mathrm{FEF}_{25-75}$ and $\mathrm{FEF}_{75-85}$ in passive smokers. WHITE and FROEB [71] provided data on 2,100 asymptomatic adults enrolled in a physical fitness programme. $\mathrm{FEF}_{25-75}$ and $\mathrm{FEF}_{75-85}$ appeared to be significantly lower among ETS exposed individuals than in unexposed nonsmokers. In addition, values in passive smokers were not significantly different from those in light (1-10 cigarettes per day) smokers and in smokers who did not inhale. Using the data of the French Cooperative Study PAARC, which in 1975 surveyed more than 7,800 adult residents 
Table 3. - Studies of environmental tobacco smoke (ETS) and lung function - positive results

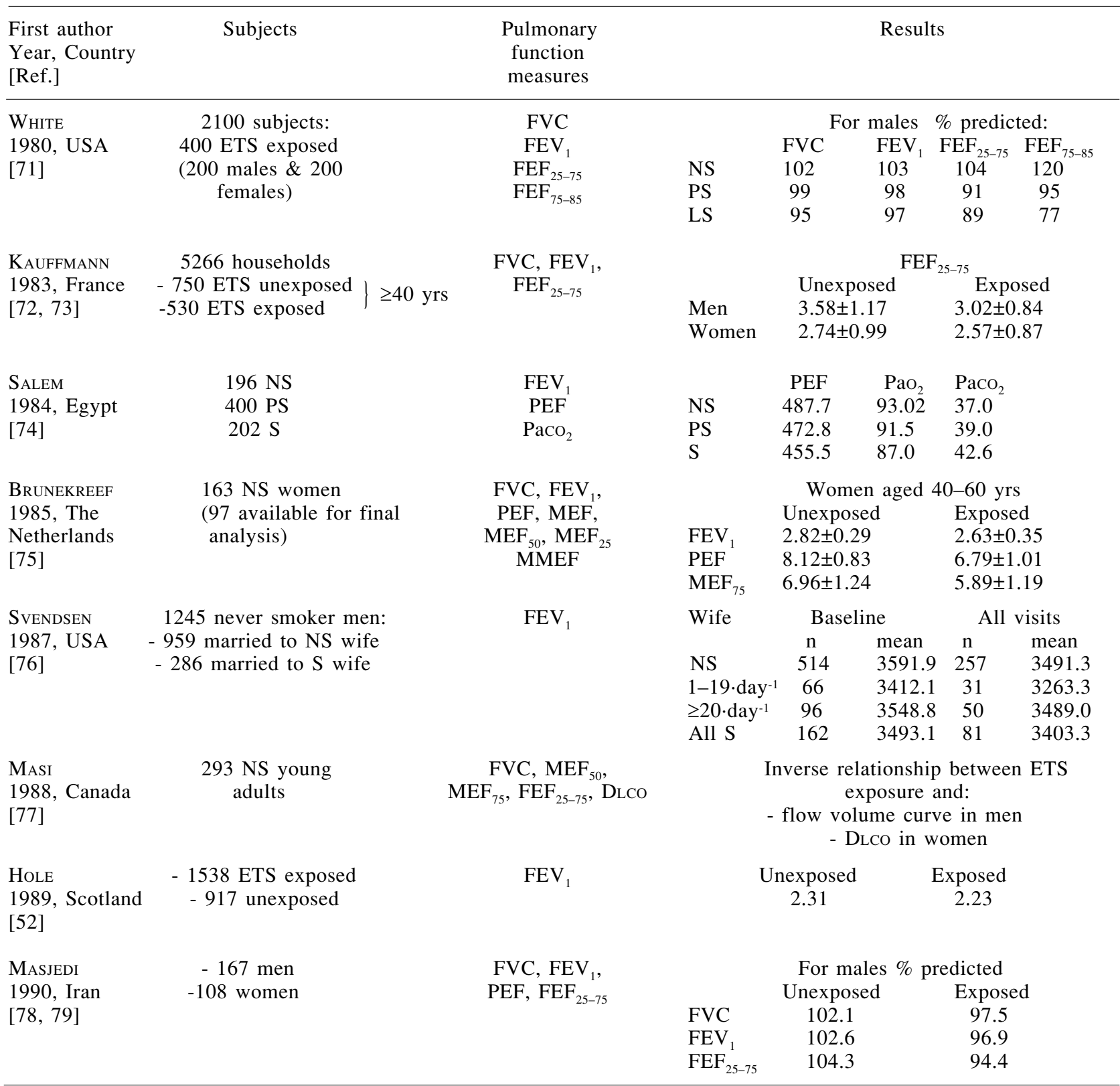

NS: nonsmoker; PS: passive smoker; S: smoker; LS: light smoker; $\mathrm{PaCO}_{2}$ : arterial carbon dioxide tension; MMEF: maximal mid-expiratory flow; $\mathrm{PaO}_{2}$ : arterial oxygen tension; DLCO: diffusing capacity of the lungs for carbon monoxide. For further abbreviations see legend to table 2 .

of seven cities throughout the country, KAUFFMANN and co-workers [72, 73] analysed an homogeneous group of 5,266 households, where both spouses were interviewed and no other adult was living. Restricting the comparison to subjects aged 40 yrs or more, i.e. presumably exposed for at least 15 yrs, and living with a current smoker of at least $10 \mathrm{~g} \cdot \mathrm{day}^{-1}$, a decrease in $\mathrm{FEV}_{1}$ and $\mathrm{FEF}_{25-75}$ was found in both sexes. Furthermore, in the more homogeneous group of women without paid work (i.e. presumably not exposed to workplace smoking) a dose-effect relationship, according to the amount of tobacco smoked by their husbands, was evident.

An Egyptian study compared 990 subjects, according to their smoking habits [74]. ETS exposed subjects had a decrease in all ventilatory parameters studied. Blood gas levels were estimated in 223 subjects; ETS exposed subjects presented a significant increase in arterial carbon dioxide tension $\left(\mathrm{PaCO}_{2}\right)$. Moreover, after voluntary exposure to ETS during $30 \mathrm{~min}$, a significant decrease in peak expiratory flow (PEF), and definite subjective reactions, namely, tightness of chest (25\%), cough (18\%), dyspnoea $(9 \%)$, wheezing $(5 \%)$, were observed.

BRUNEKREEF et al. [75] investigated the association between pulmonary function and exposure to ETS in the home, in a sample of 173 adult, nonsmoking women living in a rural area of The Netherlands. 
Table 4. - Studies of environmental tobacco smoke (ETS) and chronic obstructive pulmonary diseases (COPD)

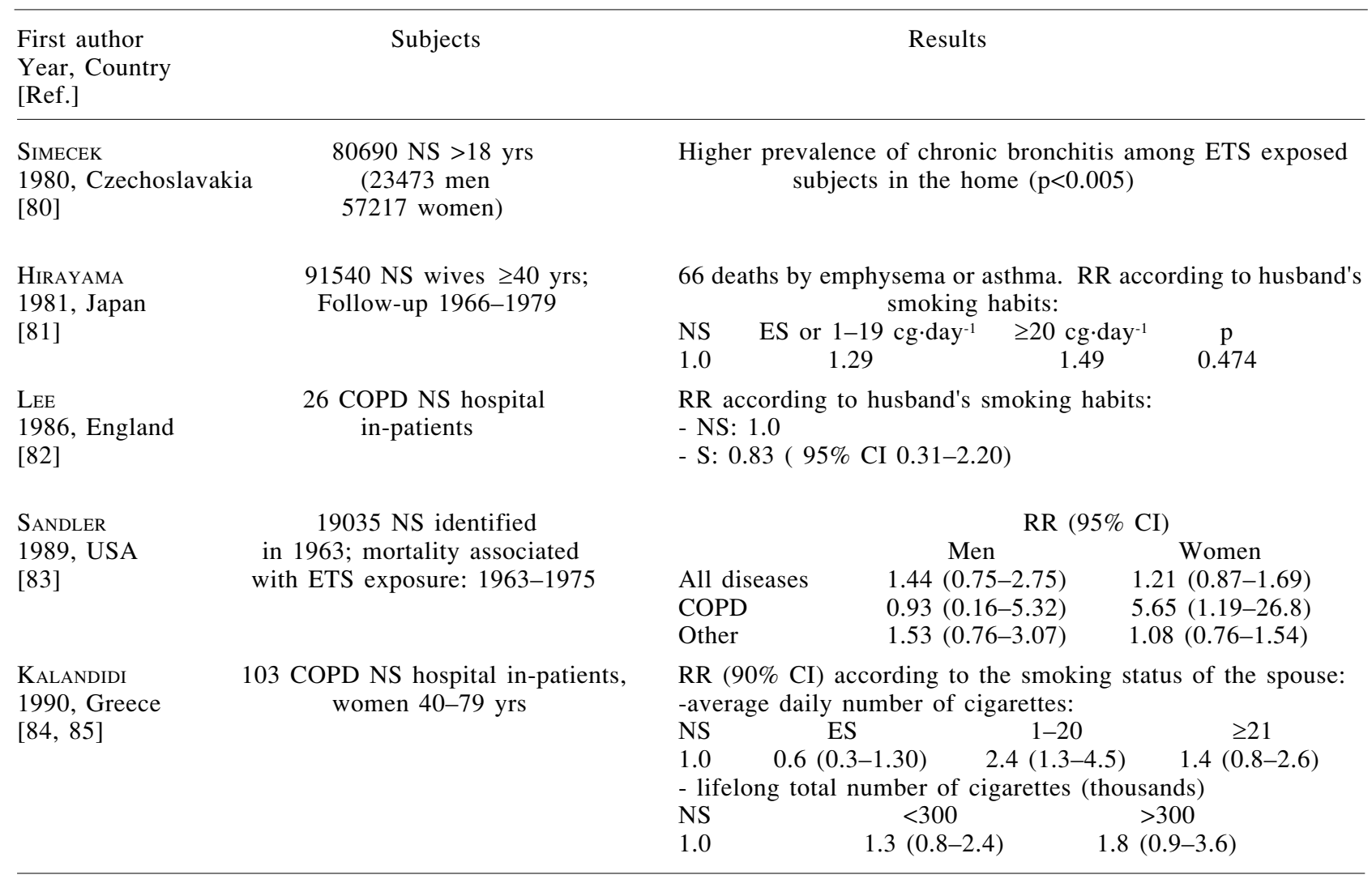

cg: cigarettes; ES: ex-smokers; CI: confidence interval. For further abbreviations see legend to tables 2 and 3.

On cross-sectional analyses, in the subgroup of women aged 40-60 yrs, PEF, $\mathrm{FEV}_{1}$ and $\mathrm{MEF}_{75}$ appeared to be significantly decreased, but no trend with level of exposure was shown.

Men aged 35-57 yrs were recruited in 18 US cities, and seen annually over 6-8 yrs for cardiovascular and other disease risk factors assessment and a medical examination [76]. Pulmonary function testing was conducted at screening, and at each annual examination. Among the participants who had never smoked, 286 were married to a smoker and 959 to a nonsmoker. Men with smoking wives had significantly lower levels of pulmonary function at baseline, as measured by $\mathrm{FEV}_{1}$. However, the difference was only about $100 \mathrm{ml}(3,493$ $\mathrm{ml}$ versus 3,591 $\mathrm{ml}$ ).

MAsi et al. [77] studied lung function of 293 nonsmoking volunteers of both sexes, 15-35 years old, from Montreal, Canada. Small airways abnormality, as noted by a decrease in $\mathrm{FEF}_{25-75 \%}, \mathrm{MEF}_{50}$, and $\mathrm{MEF}_{75}$, were reported in men passively exposed to cigarette smoke (measured as persons $\times$ yrs, or packs per day $\times$ persons $x$ yrs). A decrease of the diffusing capacity of the lung in relation to cumulative ETS exposure at work was found among women.

Participants in the West Scotland study showed that mean $\mathrm{FEV}_{1}$ was significantly higher in controls than in ETS exposed individuals [52]. Highly exposed passive smokers had significantly lower adjusted $\mathrm{FEV}_{1}$ when compared with those with low exposure. No significant difference was found between passive smokers with low exposure and controls.

MASJEDI and co-workers [78, 79] assessed the effects of exposure to ETS on pulmonary function of nonsmoking Iranian men and women. Of the 275 subjects examined, 132 (48\%) were ETS exposed, and had significant reductions in $\mathrm{FEV}_{1}, \mathrm{FVC}$ and $\mathrm{FEF}_{25-75}$. This decrease was greatest among men exposed at the workplace, whereas men exposed to ETS only at home had smaller and nonsignificant reductions in the three parameters studied. No significant difference in pulmonary function was found among the 54 women exposed to ETS, but only eight women had ETS exposure at work.

Finally, LEBOwITZ and co-workers [17] recently observed that morning PEF is decreased in subjects sleeping in bedrooms where cigarettes are smoked.

\section{Chronic obstructive pulmonary disease (COPD)}

Few studies have examined the possible association between exposure to ETS and development of COPD. They are summarized in table 4.

A study of chronic bronchitis in Czechoslovakia recorded the data obtained for the adult population of three West Bohemian districts in 1972-1975 [80]. A total of 80,690 nonsmoking adults was examined. Subjects exposed at home to ETS suffered more frequently from manifestations of chronic bronchitis (however, limited information was provided on the results). 
In an analysis of mortality among Japanese nonsmoking wives of smokers, HIRAYAMA [81] presented relative risks of death for nonsmoking women, according to their husbands' smoking habits. Based on a total of 66 deaths, a positive trend, although not significant, was observed for emphysema and asthma.

As a part of a hospital case-control study carried out in England, no relationship was found between an index of cumulative ETS exposure or the smoking status of the spouse and risk of chronic bronchitis [82].

SANDLER et al. [83] investigated the 1963-1975 mortality of 27,891 smokers and 19,035 nonsmokers resident in Washington County, Maryland. Subjects were classified according to their 1963s smoking status. Among nonsmokers, there were 1,248 men and 9,551 women married to a smoker. Mortality from respiratory diseases was higher among the ETS exposed subjects than among unexposed nonsmokers. The trend was stronger for emphysema and bronchitis among women, and for other respiratory diseases among men.

In 1982, KALANDIDI et al. [84, 85] undertook a study to investigate the association between ETS and COPD in Greek women, aged 40-79 yrs. One hundred and three incident cases, who had never smoked, and 179 nonsmoking control women were interviewed regarding the smoking habits of their husbands. Relative risks of (hospitalization for) COPD were studied by average daily number of cigarettes, as well as total life-long number of cigarettes smoked by the husband. In both instances, there were statistically significant linear trends between amount of tobacco smoked by the husband and risk of COPD for the wife.

A study of US Seventh-day Adventists noted that living with a smoker for $10 \mathrm{yrs}$ increased the risk of COPD by $7 \%$, whereas a similar occupational exposure increased the risk by $11 \%$ [86].

\section{Asthma}

The evidence regarding ETS exposure producing pulmonary changes leading to bronchospasm in asthmatic patients is sparse [87]. A broad range of respiratory tract illnesses (including asthma) and functional alterations has been attributed to the exposure of infants and children to parental (especially maternal) cigarette smoking [88]. However, the effect of ETS in adult asthmatic subjects is difficult to study and less well understood, despite the fact that many patients regard ETS as a major exacerbating factor [89].

A few observational studies are available. PIPES [90] observed that $15 \%$ of patients with respiratory allergies gave a history of their respiratory allergy being precipitated or aggravated by exposure to tobacco smoke. SPEER [36] reported results of an investigation using a questionnaire given to 191 allergic nonsmokers and 250 nonallergic nonsmokers. Allergic patients experienced more nasal symptoms, headache, cough, wheezing, sore throat and hoarseness than nonallergic patients. Similarly, WEBER and FISCHER [91] reported more irritation at work among those employees suffering from hayfever exposed to ETS, as compared to non-exposed employees. In a survey of 111 asthmatic patients, $78 \%$ reported that cigarette smoke aggravated their asthma, and one third of these were exposed at home [92].

Relevant experimental studies are summarized in table 5. SHEPHARD et al. [93] exposed 14 asthmatic patients whose baseline pulmonary function demonstrated slight previous airflow obstruction $\left(\mathrm{FEV}_{1} 74 \%\right.$ predicted $)$ - to a 2 h ETS exposure. Shortness of breath, wheezing, or tightness in the chest were experienced by five subjects. No significant changes of dynamic lung volumes were observed between sham and smoke exposure periods.

DAHMs et al. [94] exposed 10 asthmatic patients and 10 control subjects to ETS for an hour. The control subjects showed no change in pulmonary function, whereas the asthmatic group demonstrated a significant linear decrease in pulmonary function during the ETS exposure.

WIEDEMAN et al. [95] investigated the effect of acute ETS exposure both on lung function and airway reactivity (assessed by methacholine inhalation challenge testing) in a group of nine young, nonsmoking, stable asthmatic patients. Subjects were exposed for one hour to a high level of cigarette smoke. No decrease in $\mathrm{FEV}_{1}$ or $\mathrm{MEF}_{50}$ was observed, but FVC showed a small but significant decrease. There was also a slight, although significant, decrease in nonspecific bronchial reactivity, the clinical significance of which is unclear.

Suggestion can induce an attack of asthma [98]. Most of the previous studies were not able to exclude the possibility that changes in pulmonary function in asthmatic subjects were emotionally related to cigarette smoke. Therefore, URCH et al. [96] tested this hypothesis in 24 adult nonasthmatic nonsmokers and 16 asthmatic nonsmokers. They argued that if physiological responses were dominant, changes in pulmonary function should show a dose-response relationship to ETS, whereas, if psychological reactions were dominant, any dose-response gradient would be less obvious, and subjects would have correlations between functional changes and specific measures of suggestibility. Subjects were exposed for one hour to a high ETS concentration (heavy smoke), a lower concentration (moderate smoke), or control. Cigarette smoke was generated by a cigarette smoking machine, located outside the exposure chamber, but visible to the subjects. During control exposure, the cigarettes were smoked but the smoke was diverted from the exposure chamber. Serial pulmonary function tests $\left(\mathrm{FVC}, \mathrm{FEV}_{1}, \mathrm{MEF}_{50}, \mathrm{MEF}_{75}\right.$, and $\mathrm{FEF}_{50-75}$ ) were performed. Asthmatics showed significant doseresponse relationships for $\mathrm{MEF}_{50}$ at $5 \mathrm{~min}$ of exposure, and for $\mathrm{FVC}$ and $\mathrm{FEV}_{1}$ at $30 \mathrm{~min}$ of exposure; results that support a physiological rather than psychological explanation of the findings.

It has been suggested that ETS is a stimulus of airway hyperresponsiveness [99]. LeBowITZ et al. [17] stated that, after adjustment for age and sex, bronchial responsiveness is related to ETS in homes. KNIGHT and BRESLIN [99] exposed six asthmatic patients to one hour of ETS. At the end of the exposure, $\mathrm{FEV}_{1}$ had fallen 
Table 5. - Studies of environmental tobacco smoke (ETS) and asthma

\begin{tabular}{|c|c|c|c|c|c|c|c|c|}
\hline $\begin{array}{l}\text { First author } \\
\text { Year, Country } \\
\text { [Ref.] }\end{array}$ & $\begin{array}{l}\text { Patients } \\
n\end{array}$ & Exposure & & \multicolumn{5}{|c|}{ Results } \\
\hline $\begin{array}{l}\text { SHEPHARD } \\
\text { 1979, USA } \\
{[93]}\end{array}$ & 14 & $\begin{array}{l}14.6 \mathrm{~m}^{3}, 2 \mathrm{~h} \\
\text { CO: } 24 \mathrm{ppm}\end{array}$ & \multicolumn{6}{|c|}{$\begin{array}{c}\% \text { of sham exposure: } \\
100.6 \pm 50 \\
101.4 \pm 7.9 \\
124.8 \pm 85 \\
99.6 \pm 26.9\end{array}$} \\
\hline $\begin{array}{l}\text { DAHMS } \\
1981 \text {, USA } \\
{[94]}\end{array}$ & 10 controls & $30 \mathrm{~m}^{3}, \quad 1 \mathrm{~h}$ & $\begin{array}{l}\text { FVC } \\
\mathrm{FEV}_{1} \\
\mathrm{FEF}_{25-75}\end{array}$ & $\begin{array}{l}\% \\
15^{\prime} \\
-7.45 \\
-8.6\end{array}$ & $\begin{array}{l}\text { hange } \mathrm{f} \\
30^{\prime} \\
-10.9 \\
-12.9 \\
-10.9\end{array}$ & $\begin{array}{l}\text { m pre-e } \\
45^{\prime} \\
-16.2 \\
-17.5 \\
-18.4\end{array}$ & $\begin{array}{c}\text { osure } \\
60^{\prime} \\
-20.0 \\
-21.4 \\
-19.2\end{array}$ & $\begin{array}{l}\text { lue } \\
\quad \mathrm{p} \\
<0.01 \\
<0.01 \\
<0.01\end{array}$ \\
\hline $\begin{array}{l}\text { WIEDEMANN } \\
\text { 1986, USA } \\
{[95]}\end{array}$ & 9 & $\begin{array}{l}4.25 \mathrm{~m}^{3}, 1 \mathrm{~h} \\
\text { CO: } 50 \mathrm{ppm}\end{array}$ & $\begin{array}{l}\mathrm{FVC} \\
\mathrm{FEV}_{1} \\
\mathrm{MEF}_{50} \\
\mathrm{PD}_{20} \mathrm{FEV}_{1} \\
\mathrm{CoHB} \%\end{array}$ & $\begin{array}{l}\text { Pre-smc } \\
4.65 \pm 0 \\
3.46 \pm 0 \\
3.46 \pm 1 \\
0.25 \pm 0 . \\
1.71 \pm 0 .\end{array}$ & & $\begin{array}{c}\text { Post-si } \\
4.56 \pm \\
3.45 \pm \\
3.42 \pm \\
0.79 \pm \\
2.57 \pm\end{array}$ & $\begin{array}{l}\text { ke } \\
0 \\
3 \\
3 \\
2 \\
3 \\
5 \\
5\end{array}$ & $\begin{array}{c}\mathrm{p} \\
0.01\end{array}$ \\
\hline $\begin{array}{l}\text { URCH } \\
\text { 1988, Canada } \\
{[96]}\end{array}$ & $\begin{array}{l}16 \\
24 \text { controls }\end{array}$ & $\begin{array}{l}14.6 \mathrm{~m}^{3,} 1 \mathrm{~h} \\
\text { CO: } 31 \text { or } 17 \mathrm{ppm}\end{array}$ & $\begin{array}{l}\text { FVC } \\
\text { FEV }_{1}\end{array}$ & $\begin{array}{c}\text { nge from } \\
\text { Shan } \\
0 \\
+23\end{array}$ & pre-exp & $\begin{array}{l}\text { sure va } \\
\text { derate } \\
41 \\
+4\end{array}$ & $\begin{array}{c}\text { after } \\
\text { Heavy } \\
-105 \\
-71\end{array}$ & ' exposure \\
\hline $\begin{array}{l}\text { STANKUS } \\
1988, \text { USA } \\
{[97]}\end{array}$ & 21 & $26 \mathrm{~m}^{3}, 2 \mathrm{~h}$ & \multicolumn{6}{|c|}{$\begin{array}{l}7 \text { out of } 21 \text { subjects experienced a significant decline } \\
(20 \%) \text { in } \mathrm{FEV}_{1}\end{array}$} \\
\hline
\end{tabular}

$\mathrm{PD}_{20} \mathrm{FEV}_{1}$ : provocative dose of methacholine causing a $20 \%$ decrease in $\mathrm{FEV}_{1}$; CoHB: carboxyhaemoglobin; ': minutes. For further abbreviations see legend to table 2.

by $11 \%$, and $4 \mathrm{~h}$ after exposure, bronchial reactivity to inhaled histamine was increased. STANKus et al. [97] exposed 21 historically ETS sensitive subjects for $2 \mathrm{~h}$ intervals, at two distinct smoke levels. Seven of the 21 subjects $(33 \%)$ experienced a significant $(>20 \%)$ and reproducible decline in $\mathrm{FEV}_{1}$. Rechallenge studies of these subjects, 24 months later, confirmed the previous observations, and suggested that ETS sensitivity remains unchanged for relatively long (at least $2 \mathrm{yrs}$ ) periods of time in most smoke-sensitive subjects with asthma [100]. No classic late-phase pulmonary response (at 5-6 h after exposure) was observed, showing that cigarette-smoke sensitivity apparently differs from the classic immediate and late asthmatic responses induced by allergen-inhalation challenge. Pretreatment with albuterol, cromolyn, and a combination of albuterol and cromolyn, $30 \mathrm{~min}$ before ETS exposure significantly diminished airway reactivity to ETS. The same group demonstrated that almost one third of smoke-sensitive subjects with asthma and one fifth of smoke-sensitive subjects without asthma have a marked increase in bronchial hyperreactivity $6 \mathrm{~h}$ after ETS exposure [101]. DANUSER et al. [102] exposed 10 hyperreactive subjects to ETS, and observed a significant decrease of $\mathrm{FEV}_{1}, \mathrm{FVC}$, and $\mathrm{MEF}_{50}$; a dose-response relationship was found for symptoms. However, these results were not confirmed by MAGNUSSEN and co-workers [103, 104], who exposed asthmatic adults to ETS followed by bronchoprovocation test with methacholine.

Finally, the studies on the possible allergenic action of tobacco smoke present a confusing pattern [105]. The fact that there are some indications that tobacco dust may have negative health effects [106] has sometimes been taken to mean that tobacco smoke is also allergenic. No experimental evidence has been presented to support this hypothesis [107]. A study of both allergic and nonallergic subjects revealed that intolerance to tobacco smoke was common in both groups; the effect of tobacco smoke appeared to be of an irritative rather than an allergic character [36]. BASCOM et al. [46] who studied upper respiratory tract sensitivity, noted an increased responsiveness to ETS in historically ETS sensitive subjects. An allergic, IgE-mediated, mechanism seemed unlikely, since no histamine was detected, suggesting that activation of mast cells was not occurring. Further evidence against the allergenic role of tobacco smoke includes the fact that smoke causes the same types of reaction in both allergic and nonallergic individuals, few allergic patients have positive skin tests to tobacco $[97,101]$, and, finally, that smoke does not provoke such nonrespiratory conditions as the allergic dermatoses or gastrointestinal allergy.

\section{Discussion}

Involuntary smoking produces unpleasant symptoms in many individuals. The acute irritating effect of ETS on respiratory mucous membranes is well-established. These subjective complaints may be sufficient reason 
for legal regulation of smoking in confined public places. Conversely, no definite conclusion can be drawn from the studies that have investigated chronic respiratory symptoms in relation to ETS exposure. It remains controversial whether acute passive smoking is associated with important pulmonary physiological hazards. Most of the studies that have used the most sensitive indicators of pulmonary function have suggested an effect of ETS exposure; however, a number of negative studies did not support this hypothesis, and dose-response relationships have not been described [108]. The physiological significance of the small changes in pulmonary function observed in some positive studies, is unclear [19]. Most of the available studies are cross-sectional, and the relationship to long-term changes in lung function is not established. Improved characterization of susceptible subgroups is needed [29].

Four out of five studies offer support to the hypothesis of an association between ETS exposure and risk of COPD. However, excluding the study by KALANDIDI et al. [85], they have provided limited information, and were based on a small number of subjects; thus, these results have to be interpreted with caution. For example, the hospital-based study from England, in which no clear association between ETS exposure and COPD risk was found [82], was based on only 26 COPD cases, who were reduced to 16 in the analysis by cumulative ETS exposure. Conflicting evidence exists on the association in asthmatic patients between ETS exposure and appearance of symptoms and functional abnormalities (including change in bronchial responsiveness). Psychological factors do not seem to be involved, as well as any potential allergenic role of SS.

\section{Bias and confounding factors}

Considering that the association between ETS and nonneoplastic respiratory effects in adults, if it exists, is at least weak, one must wonder whether chance could explain the reported findings. Most of the studies which we have reviewed, especially the early ones, although suggestive of a positive effect, have had several deficiencies, which can substantially bias study results, increasing the difficulty of interpretation, especially if the likely effect of ETS is small [109, 110]. In particular, statistical considerations must be taken into account: by convention, a probability value less than $5 \%$ is deemed statistically significant. However, the p-value is a measure of the probability that the finding is due to chance, and it reflects the size of the sample studied. Thus, the absence of statistical significance for an association between an exposure and a disease may not necessarily be indicative of the absence of an association [111], but may reflect an inadequate sample size [22]. Considering the fact that, if real, the association between ETS exposure and adult respiratory non-neoplastic lung diseases is weak, it is therefore not surprising that the available studies, most of which have included a small number of subjects, could not achieve the level of the statistical significance.

Of particular concern, as a possible source of bias, are former and current smokers who report themselves as nonsmokers and, thus, may have been at higher risk than true nonsmokers, because of a history of smoking, and not because of exposure to ETS. Hence, a health effect from active smoking may be contaminating, and falsely increasing, the evaluation of the risk of ETS if this misclassification is more important among cases than controls. The recognized concordance of smoking habits in married couples is of particular concern [112]: a woman who claims to be a nonsmoker is more likely to be, or to have been, an actual smoker if married to a smoker, than if married to a nonsmoker. Conversely, misreporting among controls - and unrecognized exposure due to background ETS artificially elevates the proportion of exposed controls relative to cases, and contributes to underestimation of risk. It is plausible that the first hypothesis is most commonly implied in the studies on ETS and respiratory diseases.

In addition, most available studies had a poor definition of exposure, that may lead to non-differential misclassification, and to underestimation of existing associations.

However, available data suggest that misclassification of smoking status is not likely to explain the excess risk. Fontham et al. [113] found that $0.8 \%$ of lung cancer cases, $2.6 \%$ of colon cases, and $2 \%$ of population controls had very high cotinine levels, suggesting that they were actually current smokers. The International Agency for Research on Cancer (IARC) conducted a study explicitly designed to elucidate this methodological issue, in 13 centres from 10 countries, [18], and found a very high correlation between self-reported smoking habits and urinary cotinine, and indication that no more than $2-3 \%$ of self-reported "nonsmoker" were actually likely to be smokers. Finally, one must stress that because there is widespread exposure to ETS, this upward potential bias is counterbalanced by the downward bias from background ETS exposure to the supposedly unexposed group.

Very little data are available on the possible confounding effect of other risk factors. Most studies did not account for multipollutant exposures. Occupation and social class, in particular, have to be taken into account. Indeed, it has been suggested that smokers are over-represented in industrial jobs, and that there is a distinct pattern tying the social class and occupation of members of the household to different smoking patterns [114]. It is therefore conceivable that nonsmokers living with smokers could be more frequently exposed to toxic materials, that are carried into the home by members who have jobs at which they are exposed to hazardous substances. Another possibility is that ETS exposure in the workplace is an indicator of exposure to other irritants and toxic products. Also, families of industrial workers are likely to be located in areas subjected to higher levels of air pollutants, that could be related to the occurrence of COPD.

\section{Criteria for a causal association}

Criteria to consider in judging whether an association observed between some factor and disease is one of cause and effect have been extensively discussed $[115,116]$ : 
- consistency cannot be judged to exist for the studies reviewed, where results are divergent between time and countries;

- the weakness of positive associations, when found, argues against strength of association;

- as most of the studies dealing with ETS exposure and adult non-neoplastic respiratory diseases were conducted in the USA, it is difficult to argue in favour of a generalization of the results;

- a dose-response relationship has not been considered in the majority of the studies. Few studies attempted to characterize exposure more specifically than using the numbers of smokers at home. Adults may have been exposed to ETS as children, and as adults either in the home or in the workplace environment, or both. The exposure time may be many decades. No study has so far considered the combined effect of these circumstances [117]. Aspects of ETS exposure, such as ventilation, room size, number of rooms in the home, duration of contact with the active smokers, that may strongly influence total exposure, have not been taken into consideration, and may explain the differences in the results. Recent studies [118] suggest that smoking by spouses contributes a large proportion of lifetime exposure to ETS, but that other sources can be important contributors. Thus, the fact that many studies took into account only the spouse's smoking status can partially explain the negativity of the findings;

- biological plausibility: combustion of tobacco products indoors contaminates air with nearly 4,000 chemicals [2]. The sidestream smoke has been documented to contain virtually all of the same compounds that have been identified in the mainstream smoke inhaled by smokers [7]. Because of the lower temperature in the burning cone of the smouldering cigarette, most partial pyrolysis products are enriched in sidestream as compared to mainstream smoke. Obviously, sidestream smoke is diluted in a considerably large volume of air, which reduces the concentrations inhaled by the involuntary smoker in comparison to those inhaled by the active smoker. Nevertheless, involuntary smoking is accompanied by exposure to many of the toxic agents generated by tobacco combustion. Furthermore, the intake of tobacco smoke components by nonsmokers has been confirmed by studies using biological markers, such as cotinine. Thus, it is biologically plausible to assume that ETS exposure is a risk factor for lung disease in nonsmokers.

ETS exposure during childhood is known to cause childhood respiratory diseases. Such diseases may also be reflected in decreased respiratory health in adulthood. These effects have not been accounted for in the studies of ETS exposure and lung function in adults, but it is likely that they would lead to underestimation of the effects of ETS in the adult studies [28].

\section{Conclusion}

The ubiquitousness of tobacco smoke in homes, workplaces, and public and private areas has until recently made exposure to ETS virtually unavoidable [16]. In- voluntary exposure to tobacco smoke has only in the last decade been intensively investigated as a risk factor for disease in nonsmokers. Consequently, the evidence concerning ETS is more limited in scope than for active smoking, and controversy remains regarding the association of ETS with certain diseases [119]. Recent evidence suggests that passive smoking has subtle effects on the respiratory health of nonsmoking adults [28]; hence, exposure to ETS has, at the minimum, an adverse effect on the health of adults with pre-existing respiratory conditions, and is largely followed by acute irritant effects on healthy adults. Moreover, the potentially adverse effect of ETS exposure on respiratory condition is strongly plausible, according to biological considerations. However, if real, its long-term clinical significance is unclear, and supposed to be weak.

Considering the large number of studies which have resulted in widely divergent findings, methodologically improved studies with larger sample sizes are needed [29, 120]. However, full resolution would seem unnecessary for the evolution of a public policy on ETS, an air pollutant with a readily controllable source. One must not forget that ETS exposure is definitely considered as harmful to children, and as an environmental lung carcinogen for adults [27, 28].

\section{References}

1. Fielding JE. - Smoking: health effects and control. $N$ Engl J Med 1985; 313: 491-498.

2. International Agency for Research on Cancer. - Tobacco smoking. IARC monographs on the evaluation of the carcinogenic risk of chemicals to humans, Vol. 38, 1986.

3. Doll R, Gray R, Peto R, Wheatley K. - Tobaccorelated diseases. J Smoking Related Dis 1990; 1: 3-13.

4. International Agency for Research on Cancer. - Cancer: causes, occurrence, and control. IARC Scientific Publications, Lyon, Vol. 100, 1990.

5. Schelling TC. - Addictive drugs: the cigarette experience. Science 1992; 255: 430-433.

6. Mason RJ, Buist AS, Fisher EB, Merchant JA, Samet JM, Welsh CH. - Cigarette smoking and health. Am Rev Respir Dis 1985; 132: 1133-1136.

7. O'Neill IK, Brunnemann KD, Dodet B, Hoffmann D. Environmental carcinogens: methods of analysis and exposure measurement - passive smoking. IARC Scientific Publications, Lyon, Vol. 9, 1987.

8. Maclure M, Katz RB, Bryant MS, Skipper PL, Tannenbaum SR. - Elevated blood levels of carcinogens in passive smokers. Am J Public Health 1989; 79: 1381-1384.

9. Hein HO, Suadicani P, Skov P, Gyntelberg F. - Indoor dust exposure: an unnoticed aspect of involuntary smoking. Arch Environ Health 1991; 46: 98-101.

10. Feyerabend C, Higenbottam T, Russell MAH. - Nicotine concentrations in urine and saliva of smokers and nonsmokers. Br Med J 1982; 284: 1002-1004.

11. Hugod C, Hawkins LH, Astrup P. - Exposure of passive smokers to tobacco smoke constituents. Int Arch Occup Environ Health 1978; 42: 21-29.

12. Jarvis MJ, Tungstall-Pedoe H, Feyerabend C, Vesey C, Salloojee Y. - Biochemical markers of smoke absorption and self-reported exposure to passive smoking. $J$ Epidemiol Commun Health 1984; 38: 335-339.

13. Matsukura S, Taminato T, Kitano N, et al. - Effects 
of environmental tobacco smoke on urinary cotinine excretion in nonsmokers: evidence for passive smoking. N Engl J Med 1984; 311: 828-832.

14. Wald NJ, Boreham J, Bailey A, Ritchie C, Haddow JE, Knight G. - Urinary cotinine as marker of breathing other people's tobacco smoke. Lancet 1984; i: 230-231.

15. Sebben J, Pimm P, Shepard RJ. - Cigarette smoke in enclosed public facilities. Arch Environ Health 1977; 32: 53-58.

16. Friedman GD, Pettiti DB, Bawol RD. - Prevalence and correlates of passive smoking. Am J Public Health 1983; 73: 401-405.

17. Lebowitz MD, Quackenboss JJ, Krzyzanowski M, O'Rourke MK, Hayes C. - Multipollutant exposures and health responses to particulate matter. Arch Environ Health 1992; 47: 71-75.

18. Riboli E, Preston-Martin S, Saracci R, et al. - Exposure of nonsmoking women to environmental tobacco smoke: a 10 country collaborative study. Cancer Causes Control 1990; 1: 243-252.

19. Weiss ST, Tager IB, Schenker M, Speizer FE. - The health effects of involuntary smoking. Am Rev Respir Dis 1983; 128: 933-942.

20. Crawford WA. - On the health effects of environmental tobacco smoke. Arch Environ Health 1988; 43: 34-37.

21. Fielding JE, Phenow KJ. - Health effects of involuntary smoking. N Engl J Med 1988; 319: 1452-1460.

22. Eriksen MP, Lemaistre CA, Newell GR. - Health hazards of passive smoking. Ann Rev Public Health 1988; 9: 47-70.

23. US. Public Health Service. - The health consequences of smoking. A report of the Surgeon General. Washington, DC, US Government Printing Office, 1972; DHEW Publication No. (PHS) 72-7516.

24. US Public Health Service. - The health consequences of smoking: chronic obstructive lung disease. A report of the Surgeon General. Washington, DC, US Government Printing Office, 1984; DHHS Publication No. (PHS) 8450205.

25. US Public Health Service. - The health consequences of involuntary smoking. A report of the Surgeon General. Washington, DC, US Government Printing Office, 1986; DHHS Publication No. (CDC) 87-8398.

26. National Research Council. - Environmental tobacco smoke: measuring exposures and assessing health effects. Washington, DC, National Academy Press, 1986.

27. US National Institute for Occupational Safety and Health. - Environmental tobacco smoke in the workplace; lung cancer and other health effects. NIOSH Current Intelligence Bulletin 54, DHHS, CDC, 1991.

28. US Environmental Protection Agency. - Respiratory health effects of passive smoking: lung cancer and other disorders. Office of Research and Development, Washington, DC, 1992; EPA/600/6-90/006F.

29. Spitzer WO, Lawrence V, Dales R, et al. - Links between passive smoking and disease: a best-evidence synthesis. A Report of the Working Group on Passive Smoking. Clin Invest Med 1990; 13: 17-42.

30. Steenland K. - Passive smoking and the risk of heart disease. J Am Med Assoc 1992; 267: 94-99.

31. Glantz SA, Parmley WW. - Passive smoking and heart disease. Epidemiology, physiology and biochemistry. Circulation 1991; 83: 1-12.

32. Graham NMH. - The epidemiology of acute respiratory infections in children and adults: a global perspective. Epidemiol Rev 1990; 12: 149-178.

33. Lefcoe NM, Ashley MJ, Pederson LL, Keays JJ. - The health risks of passive smoking. The growing case for control measures in enclosed environments. Chest 1983; 84: 90-95.

34. Woodward A. - Passive smoking in the workplace Fictitious or real health risk? 23rd International Congress on Occupational Health, Montreal, 1990; pp. 217-249.

35. Woodward A. - Is passive smoking in the workplace hazardous to health? Scand J Work Environ Health 1991; 17: 293-301.

36. Speer F. - Tobacco and the nonsmoker: a study of subjective symptoms. Arch Environ Health 1968; 16: 443-446.

37. Weber A. - Annoyance and irritation by passive smoking. Prev Med 1984; 13: 618-625.

38. Willes SR, Fitzgerald TK, Bascom R. - Nasal inhalation challenge studies with sidestream tobacco smoke. Arch Environ Health 1992; 47: 223-230.

39. Muramatsu TA, Weber S, Akermann F. - An experimental study on irritation and annoyance due to passive smoking. Int Arch Occup Environ Health 1983; 51: 305-317.

40. Weber A, Jermini C, Grandjean E. - Irritating effects on man of air pollution due to cigarette smoke. Am J Public Health 1976; 66: 672-676.

41. National Academy of Sciences. - The airliner cabin environment: Air quality and safety. Washington, DC, National Academy Press, 1986.

42. US National Institute for Occupational Safety and Health USFAA US Public Health Service. - Health aspects of smoking in transport aircraft. Washington, DC, US Government Printing Office, 1971.

43. Mattson ME, Boyd G, Byar D, et al. - Passive smoking on commercial airline flights. J Am Med Assoc 1989; 261: 867-872.

44. Pimm PE, Silverman F, Shephard RJ. - Physiological effects of acute passive exposure to cigarette smoke. Arch Environ Health 1978; 33: 201-213.

45. Shephard RJ, Collins R, Silverman F. - Responses of exercising subjects to acute "passive" cigarette smoke exposure. Environ Res 1979; 19: 279-291.

46. Bascom R, Kulle T, Kagey-Sobotka A, Proud D. - Upper respiratory tract environmental tobacco smoke sensitivity. Am Rev Respir Dis 1991; 143: 1304-1311.

47. Barad CB. - Smoking on the job: the controversy heats up. Occup Health Safety 1979; 48: 21-24.

48. Lebowitz MD, Burrows B. - Respiratory symptoms related to smoking habits of family adults. Chest 1976; 69: 48-50.

49. Comstock GW, Meyer MB, Helsing KJ, Tockman MS. - Respiratory effects of household exposures to tobacco smoke and gas cooking. Am Rev Respir Dis 1981; 124: 143-148.

50. Kauffmann F, Dockery DW, Speizer FE, Ferris BG. Respiratory symptoms and lung function in women with passive and active smoking. Am Rev Respir Dis 1986; 133: (Abstract) A157.

51. Kauffmann F, Dockery DW, Speizer FE, Ferris BG. Respiratory symptoms and lung function in relation to passive smoking: a comparative study of American and French women. Int J Epidemiol 1989; 18: 334-344.

52. Hole DJ, Gillis CR, Chopra C, Hawthorne VM. - Passive smoking and cardiorespiratory health in a general population in the west of Scotland. Br Med J 1989; 299: 423-427.

53. Schwartz J, Zeger S. - Smoking, passive smoking, air pollution, and acute respiratory symptoms in diary study of student nurses. Am Rev Respir Dis 1985; 131: (Abstract) A27.

54. Schwartz J, Zeger S. - Passive smoking, air pollution, 
and acute respiratory symptoms in diary study of student nurses. Am Rev Respir Dis 1990; 141: 62-67.

55. White JR, Froeb HF, Kulik JA. - Respiratory illness in nonsmokers chronically exposed to tobacco smoke in the work place. Chest 1991; 100: 39-43.

56. Schilling RSF, Letai AD, Hui SL, Beck GJ, Schoenberg JB, Bouhuys A. - Lung function, respiratory disease, and smoking in families. Am J Epidemiol 1977; 106: 274-283.

57. Ferris BG, Speizer FE, Spengler JD. - Effects of sulfur oxides and respirable particles on human health. Methodology and demography of populations in study. Am Rev Respir Dis 1979; 120: 769-779.

58. PAARC Groupe coopératif. - Pollution atmosphérique et affections respiratoires chroniques ou à répétition. I. Méthodes et matériel. Bull Eur Physiopathol Respir 1982; 18: 87-99.

59. Gillis CR, Hole DJ, Hawthorne VM, Boyle P. - The effect of environmental tobacco smoke in two urban communities in the west of Scotland. Eur J Respir Dis 1984; 65 (Suppl. 133): 121-126.

60. Hammer DI, Hasselblad V, Portnoy B, Wehrle PF. Los Angeles student nurse study. Daily symptom reporting and photochemical oxidants. Arch Environ Health 1974; 28: 255-260.

61. Schwartz J, Hasselblad V, Pitcher H. - Air pollution and morbidity: a further analysis of the Los Angeles student nurse data. J Air Pollution Control Assoc 1988; 38: $158-162$

62. Jones JR, Higgins IT, Higgins MW, Keller JB. - Effects of cooking fuels on lung function in nonsmoking women. Arch Environ Health 1983; 38: 219-222.

63. Lebowitz MD, Knudson RJ, Burrows B. - Family aggregation of pulmonary function measurements. Am Rev Respir Dis 1984; 129: 8-11.

64. Lebowitz MD. - The effects of environmental tobacco smoke exposure and gas stoves on daily peak flow rates in asthmatic and nonasthmatic families. Eur $J$ Respir Dis 1984; 65 (Suppl. 133): 90-97.

65. Lebowitz MD. - Influence of passive smoking on pulmonary function: a survey. Prev Med 1984; 13: 645655.

66. Kentner M, Triebig G, Weltle D. - The influence of passive smoking on pulmonary function: a study of 1,351 office workers. Prev Med 1984; 13: 656-669.

67. Laurent AM, Bevan A, Chakroun, N, et al. - Effets sanitaires d'une exposition chronique à la fumée de tabac sur une population de non fumeurs. Rev Pneumol Clin 1992; 48: $65-70$.

68. Cuddeback JE, Donovan JR, Burg WR. - Occupational aspects of passive smoking. Am J Ind Hyg Assoc 1976; 37: 263-267.

69. Macklem PT, Mead J. - Resistance of central and peripheral airways measured by a retrograde catheter. J Appl Physiol 1967; 22: 395-401.

70. Morris JF, Koski A, Breese JD. - Normal values and evaluation of forced end-expiratory flow. Am Rev Respir Dis 1975; 111: 755-762.

71. White JR, Froeb HF. - Small airways dysfunction in nonsmokers chronically exposed to tobacco smoke. $N$ Engl J Med 1980; 302: 720-723.

72. Kauffmann F, Perdrizet S. - Effect of passive smoking on respiratory function. Eur J Respir Dis 1981; 62 (Suppl. 113): 109-110.

73. Kauffmann F, Tessier JF, Oriol P. - Adult passive smoking in the home environment: a risk factor for chronic airflow limitation. Am J Epidemiol 1983; 117: 269-280.
74. Salem ES, EL Zahby M, Senna GA, Malek A. - Pulmonary manifestations among "passive smokers". Bull Int Union Tuberc 1984; 59: 50-53.

75. Brunekreef B, Fischer P, Remijn B, van der Lende R, Schouten J, Quanjer P. - Indoor air pollution and its effects on pulmonary function of adult nonsmoking women. III. Passive smoking and pulmonary function. Int $J$ Epidemiol 1985; 14: 227-230.

76. Svendsen K, Kuller LH, Martin MJ, Ockene JK. - Effects of passive smoking in the Multiple Risk Factor Intervention Trial. Am J Epidemiol 1987; 126: 783-795.

77. Masi MA, Hanley JA, Enrst P, Becklake MR. - Environmental exposure to tobacco smoke and lung function in young adults. Am Rev Respir Dis 1988; 138: 296-299.

78. Johnson DC, Masjedi MR, Kazemi H. - Effects of passive smoking on the pulmonary function of adults. $A m$ Rev Respir Dis 1985; 131: (Abstract) A27.

79. Masjedi MR, Kazemi H, Johnson DC. - Effects of passive smoking on the pulmonary function of adults. Thorax 1990; 45: 27-31.

80. Simecek C. - Reflection of passive exposure to smoking in the home on the prevalence of chronic bronchitis in nonsmokers. Czech Med 1980; 3: 308-310.

81. Hirayama T. - Nonsmoking wives of heavy smokers have a higher risk of lung cancer: a study from Japan. Br Med J 1981; 282: 183-185.

82. Lee PN, Chamberlain J, Alderson MR. - Relationship of passive smoking to risk of lung cancer and other smoking-associated diseases. Br J Cancer 1986; 54: 97-105.

83. Sandler DP, Comstock GW, Helsing KJ, Shore DL. Deaths from all cause mortality in nonsmokers who lived with smokers. Am J Public Health 1989; 79: 163-167.

84. Kalandidi A, Trichopoulos D, Hatzakis A, Tzannes S, Saracci R. - Passive smoking and chronic obstructive lung disease. Lancet 1987; ii: 1325-1326.

85. Kalandidi A, Trichopoulos D, Hatzakis A, Tzannes S, Saracci R. - The effect of involuntary smoking on the occurrence of chronic obstructive pulmonary disease. Soz Praeventivmed 1990; 35: 12-16.

86. Euler GL, Abbey DE, Magie AR, Hodkin JE. - Chronic obstructive pulmonary disease symptom effects of longterm cumulative exposure to ambient levels of total suspended particulates and sulfur dioxide in California Seventh-day Adventist residents. Arch Environ Health 1987; 42: 213-222.

87. Zussman BM. - Tobacco sensitivity in the allergic population: a review with results of desensitization with 10 percent whole leaf tobacco extract. Ann Allergy 1980; 45: 304-309.

88. Tager IB. - Passive smoking: bronchial responsiveness and atopy. Am Rev Respir Dis 1988; 138: 507-509.

89. Cockcroft DW. - Cigarette smoking, airway hyperresponsiveness, and asthma. Chest 1988; 94: 675-676.

90. Pipes DM. - Allergy to tobacco smoke. Ann Allergy 1945; 28: 277-282.

91. Weber A, Fischer T. - Passive smoking at work. Int Arch Occup Environ Health 1980; 47: 209-221.

92. Dales RE, Kerr PE, Schweitzer I, Reesor K, Gougeon L, Dickenson G. - Asthma management preceding an emerg-ency department visit. Arch Intern Med 1992; 152: 2041-2044.

93. Shephard RJ, Collins R, Silverman F. - "Passive" exposure of asthmatic subjects to cigarette smoke. Environ Res 1979; 20: 392-402.

94. Dahms TE, Bolin JF, Slavin RG. - Passive smoking: effects on bronchial asthma. Chest 1981; 80: 530-534. 
95. Wiedemann HP, Mahler DA, Loke J, Virgulto JA, Snyder P, Matthay RA. - Acute aspects of passive smoking on lung function and airway reactivity in asthmatic subjects. Chest 1986; 89: 180-185.

96. Urch RB, Silverman F, Corey P, Shephard RJ, Cole P, Goldsmith LJ. - Does suggestibility modify acute reactions to passive cigarette smoke exposure? Environ Res 1988; 47: 34-47.

97. Stankus RP, Menon PK, Rando RJ, Glindmeyer H, Salvaggio JE, Lehrer SB. - Cigarette smoke sensitive asthma: challenge studies. J Allergy Clin Immunol 1988; 82: 331-338.

98. Spector S, Luparello TJ, Kopetsky MT, Sourahda J, Kinsman RA. - Response of asthmatics to methacholine and suggestion. Am Rev Respir Dis 1976; 113: 43-50.

99. Knight A, Breslin ABX. - Passive cigarette smoking and patients with asthma. Med J Aus 1985; 142: 194195.

100. Menon P, Stankus RP, Rando RJ, Salvaggio JE, Lehrer SB. - Asthmatic responses to passive cigarette smoke: persistence of reactivity and effect of medications. $J$ Allergy Clin Immunol 1991; 88: 861-869.

101. Menon P, Rando RJ, Stankus RP, Salvaggio JE, Lehrer SB. - Passive cigarette smoke - challenge studies: increase in bronchial hyperreactivity. J Allergy Clin Immunol 1992; 89: 560-566.

102. Danuser B, Weber A, Hartmann AL, Krueger H. Effects of a bronchoprovocation challenge test with cigarette sidestream smoke on sensitive and healthy adults. Chest 1993; 103: 353-358.

103. Magnussen H, Jörres R, Oldigs M. - Effect of one hour of passive cigarette smoking on lung function and airway responsiveness in adults and children with asthma. Clin Invest 1992; 70: 368-371.

104. Jörres R, Magnussen H. - Influence of short-term passive smoking on symptoms, lung mechanics and airway responsiveness in asthmatic subjects and healthy controls. Eur Respir J 1992; 5: 936-944.

105. Lehrer SB, Stankus RP, Salvaggio J. - Tobacco smoke sensitivity: a result of allergy? Ann Allergy 1986; 56: 369-379.

106. Viegi G, Paggiaro PL, Begliomini E, Vaghetti E, Paoletti P, Giuntini C. - Respiratory effects of occupational exposure to tobacco dust. $\mathrm{Br}$ J Ind Med 1986; 43: 802808.

107. Rylander R. - Review of studies on environmental tobacco smoke. Scand J Respir Dis 1974; (Suppl. 91): 10-20.

108. Wu-Williams AH, Samet JM. - Environmental tobacco smoke: exposure-response relationships in epidemiologic studies. Risk Anal 1990; 10: 39-48.

109. Florey $\mathrm{C}$ du V. - Weak associations in epidemiological research: some examples and their interpretation. Int J Epidemiol 1988; 7 (Suppl.): 950-954.

110. Angell M. - The interpretation of epidemiologic studies. $N$ Engl J Med 1990; 323: 823-825.

111. Schlesselman JJ. - "Proof" of cause and effect in epidemiologic studies: criteria for judgement. Prev Med 1987; 16: 195-210.

112. Lee PN. - Lung cancer and passive smoking: association and artefact due to misclassification of smoking habits? Toxicol Lett 1987; 35: 157-162.

113. Fontham ETH, Correa P, Wu-Williams A, et al. Lung cancer in nonsmoking women: a multicenter casecontrol study. Cancer Epidemiol, Biomarkers \& Prevention 1991; 1: 35-43.

114. Sterling TD, Weinkam JJ. - The confounding of occupation and smoking and its consequences. Soc Sci Med 1990; 30: 457-467.

115. US Public Health Service. - Smoking and health. Report of the Advisory Committee to the Surgeon General of the Public Health Service. Public Health Service 1964; Publ. No. 1103. Washington DC, US GPO.

116. Hill AB. - The environment and disease: association or causation? Proc $R$ Soc Med 1965; 58: 295-300.

117. Bake B. - Does environmental tobacco smoke affect lung function? Eur J Respir Dis 1984; 65 (Suppl. 133): $85-87$.

118. Janerich DT, Thompson D, Varela LR, et al. - Lung cancer and exposure to tobacco smoke in the household. N Engl J Med 1990; 323: 632-636.

119. Samet JM, Marbury MC, Spengler JD. - Health effects and sources of indoor air pollution. Part 1. Am Rev Respir Dis 1987; 136: 1486-1508.

120. Shephard RJ. - Respiratory irritation from environmental tobacco smoke. Arch Environ Health 1992; 47: $123-130$. 